\title{
Values and Norms Matter: Ketidakikutsertaan Indonesia dalam Regional Cooperation Agreement on Combating Piracy and Armed Robbery against Ships (ReCAAP)
}

\author{
Mayora Bunga Swastika \\ Universitas Indonesia
}

\begin{abstract}
This article examines Indonesia's choice to not join the Regional Cooperation Agreement on Combating Piracy and Armed Robbery against Ships in Asia (ReCAAP). Piracy is a transnational crime that requires cooperation to deal with. Asian waters has a high level of piracy, especially in the Malacca Strait and Indonesian Waters. ReCAAP, as a regional institution, was formed to deal with piracy and armed robbery against ships in Asian waters. Indonesia has been choosing not to join ReCAAP to combat piracy and armed robbery against ships. The purpose of this article is to explain the causes of Indonesia's rejection to join ReCAAP. This article uses literature study by collecting related data piracy in the Malacca Strait and Indonesian waters. Beside, this article collecting related data about Indonesia foreign policy. In the end, this article shows there are non-material factors that influencing Indonesia's behavior not to join ReCAAP. The non-material factors are historical, values, and norms.
\end{abstract}

Keywords: Indonesia, piracy, Malacca Strait, maritime cooperation, ReCAAP, values, norms

\begin{abstract}
Abstrak
Artikel ini menjelaskan tentang sikap Indonesia yang tidak bergabung dengan Regional Cooperation Agreement on Combating Piracy and Armed Robbery against Ships in Asia (ReCAAP). Perompakan merupakan kejahatan transnasional yang dibutuhkan kerjasama untuk menanganinya. Kawasan Asia memiliki tingkat perompakan yang tinggi, terutama di wilayah Selat Malaka dan wilayah perairan Indonesia. ReCAAP sebagai institusi regional dibentuk untuk menangani pembajakan dan perompakan di wilayah perairan Asia, terutama di wilayah Selat Malaka dan perairan Indonesia yang memiliki tingkat kasus perompakan yang tinggi. Namun sejak tahun 2007 ketika ReCAAP dibentuk hingga saat ini, Indonesia memilih untuk tidak bergabung bersama ReCAAP dalam upaya menangani perompakan. Tujuan dari artikel ini adalah mengetahui faktor yang memengaruhi Indonesia memilih untuk tidak bergabung dengan ReCAAP untuk menangani perompakan yang terjadi di Selat Malaka dan perairan Indonesia. Artikel ini menggunakan studi pustaka dengan mengumpulkan data-data yang terkait dengan kasus perompakan yang terjadi di Selat Malaka dan perairan Indonesia serta kebijakan luar negeri Indonesia. Pada akhirnya, artikel ini menunjukkan bahwa terdapat faktor non-material yang memengaruhi perilaku Indonesia, yaitu adanya historis, nilai, dan norma yang mendorong Indonesia tidak bergabung dengan ReCAAP.
\end{abstract}

Kata-kata kunci: Indonesia, perompakan, Selat Malaka, kerjasama maritim, ReCAAP, nilai, norma 


\section{Pendahuluan}

The Regional Cooperation Agreement on Combating Piracy and Armed Robbery against Ships in Asia (ReCAAP) merupakan salah satu bentuk kerjasama antar negara untuk menangani isu perompakan dan pembajakan di wilayah Asia. ReCAAP adalah suatu perjanjian yang berlaku mulai 4 September 2006. Sampai saat ini, 20 negara telah bergabung dalam ReCAAP , terdiri dari 14 negara Asia, 4 negara Eropa, Australia, dan Amerika Serikat (ReCAAP, 2017). Implementasi ReCAAP meliputi pertukaran informasi antara negara-negara penandatangan terkait perompakan di wilayah Asia, melakukan pelatihan terkait upaya penanggulangan perompakan di wilayah Asia, dan melakukan peningkatan kapasitas negara-negara penandatangan untuk dapat menanggulangi perompakan di wilayah Asia.

ReCAAP dimaksudkan untuk menangani kasus perompakan yang cukup tinggi di Asia. Menurut laporan tahunan International Maritime Bureau (IMB), terdapat beberapa wilayah di Asia yang mengalami kasus perompakan cukup tinggi. Wilayah Indonesia dan Selat Malaka serta Singapura merupakan wilayah yang terjadi kasus perompakan lebih tinggi dibandingkan dengan wilayah lain di Asia. Selain itu, wilayah lain di Asia yang terjadi perompakan pada tahun 2000-2015 adalah wilayah Malaysia, Laut Cina Selatan, Filipina, Thailand, Myanmar, dan Vietnam.

Indonesia sebagai negara maritim telah melakukan kerjasama sebagai upaya menangani kasus perompakan yang tinggi di wilayah perairan Indonesia dan Selat Malaka. Indonesia dan Selat Malaka merupakan wilayah dengan tingkat kasus perompakan yang tergolong lebih tinggi dibandingkan dengan wilayah lain. Indonesia melakukan kerjasama dengan Malaysia dan Singapura untuk menangani perompakan khususnya di wilayah Selat Malaka. Kerjasama litoral states ini berawal pada 16 November 1971 dengan membentuk Joint Statement. Pada 24 Februari 1977, Indonesia dengan Malaysia dan Singapura memperkuat Joint Statement dengan upaya keamanan navigasi dan koordinasi di wilayah Selat Malaka (Khalid, 2009). Selanjutnya, pada tahun 2004, Indonesia dengan Malaysia dan Singapura memperkuat kerjasama sebagai upaya penanganan perompakan di wilayah Selat Malaka. Indonesia, Malaysia, dan Singapura melakukan patroli di Selat Malaka sebagai upaya menangani perompakan (Liss, 2013).

Meskipun Indonesia telah melakukan kerjasama dengan Malaysia dan Singapura untuk menangani perompakan, namun Indonesia tidak bergabung dengan ReCAAP. Hal ini menimbulkan pertanyaan, mengingat wilayah Indonesia dan Selat Malaka merupakan wilayah dengan kasus perompakan yang tinggi dibandingkan wilayah lain setiap tahunnya.

Negara-negara anggota ReCAAP adalah Australia, Bangladesh, Brunei Darussalam, Kamboja, China, Denmark, India, Jepang, Republik Korea, Laos, Myanmar, Belanda, Norwegia, Filipina, Singapura, Sri Lanka, Thailand, Inggris, Vietnam, dan Amerika Serikat. 
Indonesia juga merupakan negara maritim yang membuat Indonesia perlu memberikan perhatian terhadap keamanan maritim di wilayahnya. Sehingga, terdapat faktor tertentu terkait ketidakikutsertaan Indonesia dalam ReCAAP untuk menangani perompakan, baik di Selat Malaka maupun wilayah Indonesia.

Terdapat beberapa tulisan yang telah menjelaskan terkait kerjasama Indonesia di bidang maritim dan upaya kerjasama menangani perompakan di Selat Malaka. Quirk dan Bradford (2015) menjelaskan bahwa poros maritim yang dicetuskan oleh Indonesia pada masa pemerintahan Presiden Joko Widodo dapat menjadi peluang baru Amerika Serikat. Indonesia dan Amerika Serikat membutuhkan kerjasama dengan strategi engagement, baik di secara diplomatik, ekonomi, maupun militer. Sementara itu, Pattiradjawane dan Soebagjo (2015) menjelaskan bahwa poros maritim oleh Indonesia dapat menjadikan Indonesia memiliki peran penting dalam kawasan. Hal ini dapat mengakibatkan win-win solution dengan negaranegara lain sebagai upaya menciptakan stabilitas keamanan dan kekayaan bagi wilayah Asia. Terkait hubungan dengan China, Pattiradjawane (2016) menjelaskan kebijakan Indonesia pada masa pemerintahan Presiden Joko Widodo untuk melakukan balancing kepentingan nasional Indonesia.

Terkait dengan karakteristik kebijakan luar negeri Indonesia kontemporer, Connelly (2015) menjelaskan bahwa pada masa pemerintahan Presiden Joko Widodo ini Indonesia memiliki visi terkait kedaulatan Indonesia dan agenda maritim. Visi dan misi Joko Widodo ini menyoroti pentingnya kedaulatan (sovereignty) dan kemandirian (autonomy). Rosyidin (2017) juga menjelaskan bahwa kebijakan luar negeri Indonesia pada masa pemerintahan Joko Widodo tidak mengejar status internasional meskipun Indonesia tidak mengabaikan statusnya dalam komunitas internasional. Lebih lanjut, Rosyidin menjelaskan empat karakteristik kebijakan luar negeri pada masa pemerintahan Joko Widodo yaitu pentingnya kedaulatan dan martabat nasional, penyempitan ruang lingkup kepentingan strategis Indonesia, kepentingan nasional berdasarkan pada kapabilitas domestik, dan fokus pada kekuatan ekonomi (wealth), meningkatkan kemampuan pertahanan maritim (power), dan menjaga kedaulatan serta perlindungan warga negara di luar negeri (security). Terkait hal ini, Febrica (2015) menjelaskan bahwa Indonesia memilih untuk melakukan kerjasama ketika keuntungan yang diperoleh lebih besar dibandingkan dengan biaya yang dikeluarkan.

Berbeda dengan tulisan-tulisan yang telah disebutkan, Lee dan McGahan (2015) membahas adanya norma dalam melakukan kerjasama antar negara. Lee dan McGahan menjelaskan bahwa negara di sekitar Selat Malaka, yaitu Indonesia, Malaysia, dan Singapura dalam menangani perompakan tidak hanya didasarkan pada kepentingan materiil dan 
strategis. Kerjasama antara littoral states tersebut didorong oleh proses norm subsidiarity. Negara-negara lemah melakukan kerjasama untuk melindungi wilayah dari campur tangan negara di luar kawasan yang memiliki power lebih kuat. Lebih lanjut, Lee dan McGahan menjelaskan bahwa Indonesia, Malaysia, dan Singapura melakukan kerjasama menangani perompakan di Selat Malaka sebagai upaya pencegahan kekuatan luar kawasan mendominasi penanganan perompakan di Selat Malaka. Tulisan dari Lee dan McGahan ini juga menunjukkan bahwa ide lokal seperti kedaulatan dan prinsip non-intervensi membentuk tantangan dalam kerjasama multilateral.

Tulisan ini menggunakan pandangan konstruktivis untuk menganalisis faktor yang membuat Indonesia tidak bergabung dengan ReCAAP. Tulisan ini melihat dari sisi non-material dalam memberikan analisis ketidakikutsertaan Indonesia dalam ReCAAP. Adanya nilai dan norma yang dibawa oleh ReCAAP dan Jepang memengaruhi keputusan Indonesia tidak bergabung dalam ReCAAP. Selain itu, secara historis, pembentukan ReCAAP yang tidak melibatkan Indonesia sebagai negara kepulauan juga memengaruhi tindakan Indonesia tidak bergabung dengan ReCAAP. Pada akhirnya, berdasarkan nilai dan norma, Indonesia lebih condong untuk melakukan kerjasama secara bilateral maupun trilateral dengan negara-negara tetangga untuk menangani perompakan di Selat Malaka.

\section{Kerjasama Internasional dalam Perspektif Teoritis}

Pandangan neorealisme dan neoliberalisme menjelaskan kerjasama dengan memerhatikan faktor material. Neorealisme memandang kerjasama dengan lebih pesimis. Hal ini seperti yang disampaikan Mearsheimer (1995) bahwa kerjasama sulit tercapai karena negara memiliki orientasi untuk memeroleh kekuasaan dan kepentingan nasional. Alasan negara melakukan kerjasama adalah karena adanya keuntungan relatif (relative gains). Grieco (1988) menjelaskan bahwa relative gains menjadikan hubungan internasional adalah zero-sum game dimana negara bersaing untuk mendapatkan keuntungan yang lebih besar dari negara lain. Hal ini menunjukkan bahwa negara akan melakukan kerjasama ketika keuntungan yang didapatkan lebih besar dibandingkan dengan negara lain.

Berbeda dengan neorealisme, neoliberalisme lebih optimis dalam memandang kerjasama. Keohane dan Nye (2012: 6) menjelaskan bahwa saling ketergantungan merupakan hal yang penting dalam politik dunia, sehingga kerjasama juga merupakan hal penting untuk mewujudkan saling ketergantungan antar negara. Lebih lanjut, Keohane dan Martin (1995) menjelaskan bahwa keuntungan mutlak (absolute gains) dari kerjasama yang cukup besar menyebabkan relative gains cenderung memiliki efek minimal terhadap kerjasama. Hal ini menunjukkan bahwa negara 
mempertimbangkan absolute gains dalam melakukan kerjasama. Negara tidak memandang keuntungan yang didapat lebih besar atau lebih kecil, melainkan negara tetap mendapatkan keuntungan dari suatu kerjasama.

Viotti dan Kauppi (2009: 196) menjelaskan terkait tipe dari kerjasama internasional. Pada Gambar 1.1 menunjukkan pola kerjasama dan konflik. Gambar 1.1 menunjukkan bahwa Viotti dan Kauppi membagi zona kerjasama internasional dan zona konflik internasional. Ketika hubungan antar negara memiliki harmoni atau keselarasan (harmony), maka kemungkinan yang terjadi antar negara itu adalah kerjasama internasional. Gambar 1.1 juga menunjukkan zona kerjasama internasional ini dimulai dengan koordinasi, kerjasama suatu isu tertentu, kemudian extensive collaboration. Jika kerjasama antar negara semakin selaras, maka akan mencapai extensive collaboration sebagai bentuk kerjasama yang erat. Negara-negara yang mencapai extensive collaboration ini akan semakin meningkatkan aktivitas positif dalam kerjasama. Begitu pula ketika antar negara mengalami perselisihan (discord), maka kemungkinan yang terjadi antar negara itu adalah konflik. Negara-negara yang mencapai konflik ini akan semakin meningkatkan perilaku negatif antar negara yang berkonflik.

\section{Gambar 1}

Pola Kerjasama dan Konflik dalam Hubungan Internasional

\begin{tabular}{|c|c|c|c|c|c|c|}
\hline $\begin{array}{l}\text { Complete } \\
\text { Hannony }\end{array}$ & & $\begin{array}{c}\text { Zone of } \\
\text { Intemational } \\
\text { Cooperation }\end{array}$ & & $\begin{array}{c}\text { Zone of } \\
\text { Intennational } \\
\text { Conflict }\end{array}$ & \multicolumn{2}{|c|}{$\begin{array}{c}\text { Conmplete } \\
\text { Discord }\end{array}$} \\
\hline \multicolumn{3}{|c|}{$\leftarrow \begin{array}{l}\text { Increasingly Positive } \\
\text { Activities }\end{array}$} & $\begin{array}{l}\text { Middle } \\
\text { Zone }\end{array}$ & \multicolumn{3}{|c|}{$\begin{array}{l}\text { Increasingly Negative } \rightarrow \\
\quad \text { Activities }\end{array}$} \\
\hline $\begin{array}{l}\text { Extensive } \\
\text { Collaboration }\end{array}$ & $\begin{array}{l}\text { Working } \\
\text { issues } \\
\text { jointly }\end{array}$ & Coordinating & $\begin{array}{l}\text { Consulting } \\
\text { Notifying }\end{array}$ & $\begin{array}{l}\text { Separating } \\
\text { and } \\
\text { withdrawing }\end{array}$ & $\begin{array}{l}\text { Working } \\
\text { at cross } \\
\text { purposes }\end{array}$ & $\begin{array}{l}\text { Obstructing } \\
\text { actions } \\
\text { Conflict }\end{array}$ \\
\hline
\end{tabular}

Sumber: Viotti dan Kauppi (2009: 196)

Kerjasama internasional dapat dipengaruhi oleh hal materiil, seperti yang dijelaskan oleh pandangan neorealisme dan neoliberalisme. Hal ini juga menyebabkan terjadinya extensive collaboration dapat dipengaruhi oleh adanya faktor materiil. Relative gains maupun absolute gains merupakan faktor materiil yang dapat memengaruhi terjadinya extensive collaboration. Selain itu, adanya koordinasi dan kerjasama suatu isu tertentu dapat dipengaruhi oleh pertimbangan relative maupun absolute gains. Pertimbangan keuntungan ini pada akhirnya dapat mendorong suatu negara akan melakukan extensive collaboration ataupun hanya sebatas koordinasi dan kerjasama dalam isu tertentu. Seperti yang telah dijelaskan bahwa extensive collaboration ini 
merupakan bentuk kerjasama yang terdapat keselarasan maksimal. Viotti dan Kauppi (2009: 196) menyebutkan bahwa extensive collaboration ini merupakan komitmen negara untuk melakukan kerjasama dalam jangka waktu panjang dan tidak dibutuhkan tawar menawar (bargaining).

Berbeda dengan pandangan neorealisme dan neoliberalisme, pandangan konstruktivisme menyoroti hal non-materiil dalam menjelaskan suatu fenomena. Reus-Smit (2005: 196) menjelaskan tiga asumsi dasar konstruktivis yang dapat menjelaskan suatu fenomena internasional. Asumsi pertama adalah terdapat faktor normative atau ideational yang membentuk perilaku aktor sosial-politik dan negara. Faktor normatif ini sama pentingnya dengan faktor materiil yang dijelaskan oleh neorealisme dan neoliberalisme. Konstruktivis memiliki argumen bahwa shared ideas, beliefs, dan values dapat dengan kuat memengaruhi perilaku politik dan sosial.

Asumsi kedua menurut Reus-Smit (2005: 197) adalah identitas aktor merupakan faktor non-materiil yang memengaruhi kepentingan dan perilaku. Suatu negara memiliki identitas yang memengaruhi kepentingan dan kemudian kepentingan ini memberikan kontribusi terhadap perilaku negara. Wendt (1992) menyatakan bahwa identitas merupakan dasar dari suatu kepentingan. Lebih lanjut, bagaimana suatu negara membangun kepentingan merupakan hal penting untuk menjelaskan fenomena politik internasional. Kepentingan ini dapat dijelaskan dengan memahami identitas sosial dari individu maupun negara. Kepentingan yang dimaksud bukan hanya kepentingan materiil, melainkan juga termasuk kepentingan non-materiil seperti ide, nilai, dan norma.

Selanjutnya, Reus-Smit (2005: 197-198) menjelaskan asumsi ketiga dari konstruktivis yang menyebutkan bahwa agen dan struktur merupakan hal yang saling dibentuk. Dalam hal ini, pengetahuan juga memiliki peran untuk membentuk suatu identitas dan kepentingan. Ide dan norma mendefinisikan identitas berkaitan dengan pola ekonomi, politik, dan budaya yang melekat pada aktor. Identitas ini juga dapat dibentuk berdasarkan pola yang dilakukan secara terus-menerus atau memiliki sifat kontinuitas. Hal ini menunjukkan bahwa identitas negara dibangun berdasarkan perilaku yang telah dilakukan secara berkelanjutan dan memiliki pola.

Konstruktivisme juga menjelaskan adanya norm subsidiarity yang memengaruhi suatu kerjasama antar negara. Lee dan McGahan (2015) menyebutkan bahwa negara yang lebih lemah menggunakan norm subsidiarity karena institusi internasional yang didominasi oleh negara besar tidak merefleksikan kepentingan dan identitas negara yang lebih lemah. Norm subsidiarity merupakan cara untuk membuat otonomi regional tanpa adanya campur tangan kekuatan eksternal. Hal ini menyebabkan kelompok regional mencegah pihak luar campur tangan dalam isu yang merupakan 
agenda lokal dari negara. Negara membuat norm subsidiarity ini dipicu oleh adanya prinsip non-intervensi dalam hubungan internasional.

\section{Kebijakan Anti-Piracy di Asia Tenggara}

Perompakan merupakan kejahatan transnasional yang juga terjadi di wilayah Asia Tenggara dan dapat menimbulkan ancaman baginegara-negara kawasan Asia Tenggara maupun kawasan lain. Ancaman perompakan yang terjadi di wilayah Asia Tenggara ini kemudian mendorong negara-negara Asia Tenggara untuk melakukan kerjasama dalam menanganinya. Pada awalnya, Indonesia, Malaysia, dan Singapura mulai memberikan perhatian untuk menangani perompakan di Selat Malaka dan Selat Singapura pada tahun 1990an. Kemudian, pada tahun 1997, ASEAN mengadopsi the ASEAN Declaration on Transnational Crime untuk menangani kejahatan transnasional termasuk perompakan (Chaikin, 2005: 128). Selanjutnya, respon untuk menangani perompakan di Asia Tenggara juga dilakukan oleh negara di kawasan lain.

Jepang merupakan negara yang memberikan perhatian terhadap perompakan di kawasan Asia Tenggara. Respon anti-piracy yang dilakukan Jepang pada awalnya dapat dilihat dari patroli multilateral yang dilakukan untuk memerangi perompakan. Jepang juga membentuk coast guard regional di Asia Tenggara pada tahun 1997. Coast guard dibentuk untuk meningkatkan kapabilitas maritim di Asia Tenggara baik secara teknis maupun operasional. Selain itu, Jepang bersama Indonesia dan Malaysia juga melakukan patroli trilateral (Black, 2014: 125). Pembentukan coast guard tersebut menunjukkan awal perhatian Jepang terhadap keamanan maritim di Asia Tenggara.

Mulai akhir tahun 1999, Jepang semakin menunjukkan perhatiannya dalam menangani perompakan yang terjadi di Asia Tenggara dengan melakukan konferensi-konferensi membahas anti-piracy. Jepang melihat perompakan dapat mengganggu stabilitas ekonomi di kawasan, sehingga Jepang menekankan perlunya kerjasama untuk menangani perompakan dan hal tersebut disampaikan oleh Perdana Menteri Jepang Keizo Obuchi di ASEAN + Jepang Summit pada November 1999. Sebagai aksi nyata, pada November 2000 Japan Coast Guard berkunjung ke India dan Malaysia untuk melakukan latihan bersama dalam upaya memerangi perompakan (MOFA Japan, 2001).

Selanjutnya, Jepang merupakan negara pelopor pembentukan kerjasama untuk menanggulangi perompakan dengan pembentukan ReCAAP dan dilanjutkan dengan ReCAAP Information Sharing Centre (ReCAAP ISC). Japan's Ministry of Foreign Affairs bersama Japan's Coast Guard membentuk ReCAAP ISC pada 29 November 2006 yang didirikan di Singapura. Jepang juga menduduki posisi penting dalam ReCAAP ISC. Yoshiako Ito dari Jepang terpilih menjadi Executive Director pertama dalam 
ReCAAP ISC. Takanori Matsumoto, seorang mantan Japan's Coast Guard, menjadi asisten Executive Director yang bertanggung jawab atas program ISC. Jepang juga memberikan dana sebesar US\$ 141.921 yang diberikan untuk biaya operasional ReCAAP ISC (MOFA Japan, 2006).

Peran dominan Jepang dalam ReCAAP sudah terlihat sejak awal pembentukan ReCAAP. Pada April 2000, Jepang mengadakan Regional Conference on Combating Piracy and Armed Robbery against Ships di Tokyo. Selanjutnya, pada Oktober 2001, Jepang mengadakan konferensi yang sama di Tokyo. Konferensi ini dibuat oleh Jepang untuk membentuk kerjasama regional dalam upaya menangani perompakan di wilayah Asia. Pada tahun 2002, Jepang melakukan negosiasi dengan negara-negara selain anggota ASEAN, yaitu Bangladesh, China, India, Republik Korea, dan Sri Lanka. Pada akhirnya, kesepakatan membentuk ReCAAP terjadi pada 11 November 2004 di Singapura dan mulai diterapkan pada 4 September 2006. Setelah ReCAAP terbentuk, implementasi-implementasi dilakukan sebagai upaya penanganan terhadap perompakan. Salah satu implementasi ReCAAP adalah membentuk ReCAAP ISC di Singapura pada tahun 2006 disusul oleh pembentukan ISC di negara-negara yang menandatangani ReCAAP (ReCAAP, 2016).

Di bawah kepemimpinan Jepang, kerjasama dalam ReCAAP ISC memberikan kontribusi kinerja dengan sistematis terkait pertukaran informasi perompakan di wilayah Asia. Setiap negara memiliki Focal Point yang digunakan untuk pertukaran informasi dengan negara-negara lain terkait insiden perompakan. Keempat belas negara penandatangan juga secara khusus menunjuk departemen di negaranya untuk menjadi Focal Point.

Peran yang telah dilakukan oleh Jepang dalam upaya anti-piracy di wilayah Asia dan pembentukan ReCAAP menunjukkan bahwa Jepang sangat menaruh perhatian pada penanganan perompakan di wilayah Asia. Jepang memberikan perhatian terhadap perompakan yang terjadi di wilayah Asia termasuk wilayah Selat Malaka yang memiliki jumlah kasus perompakan cukup tinggi. Jepang telah melakukan peningkatan kapasitas bagi negara penandatangan ReCAAP dan juga memberikan sumbangan secara material untuk pengembangan operasional ReCAAP. Hal ini semakin menunjukkan bahwa Jepang memiliki perhatian terhadap penanganan perompakan di wilayah Asia termasuk Selat Malaka.

Berbeda dengan Jepang, Indonesia yang bersinggungan langsung dengan Selat Malaka secara geografis tidak bergabung dengan ReCAAP. Sejak awal ReCAAP mulai dirintis, Indonesia juga tidak turut memiliki peran. Jepang yang menginisiasi pembentukan ReCAAP melakukan negosiasi dengan bertempat di Tokyo. Selain itu, Jepang membangun ISC pertama di Singapura. Jepang juga melakukan negosiasi dengan negara-negara di luar anggota ASEAN seperti Bangladesh, China, India, 
Republik Korea, dan Sri Lanka untuk merintias pembentukan ReCAAP. Namun, Jepang tidak melakukan dialog khusus dengan Indonesia. Hal ini menunjukkan bahwa sejak awal terbentuknya ReCAAP, Indonesia tidak berperan secara langsung meskipun secara geografis letak Indonesia bersinggungan dengan Selat Malaka. Dalam hal ini, Jepang lebih berperan untuk membentuk inisiatif penanganan perompakan yang cukup tinggi di wilayah Selat Malaka.

\section{Pandangan Indonesia terhadap Keamanan Maritim}

Kurangnya peran Indonesia ketika pembentukan ReCAAP dipengaruhi oleh kebijakan luar negeri Indonesia pada saat pembentukan ReCAAP. Kebijakan luar negeri Indonesia pada tahun 2000-2013 tidak memiliki perhatian utama terhadap inisiatif-inisiatif keamanan maritim (Febrica, 2017: 67). Pada masa pemerintahan Presiden Abdurrahman Wahid tahun 1999-2001, kebijakan luar negeri Indonesia memiliki fokus memperbaiki kondisi domestik pasca krisis ekonomi tahun 1998. Pada masa pemerintahan Presiden Megawati Soekarno Putri tahun 2001-2004, kondisi keamanan yang mendapat perhatian adalah terkait terorisme akibat adanya serangan teroris Bom Bali (Bandoro, 2014: 252). Sedangkan, pada masa pemerintahan Presiden Susilo Bambang Yudhoyono tahun 2004-2014, kebijakan luar negeri Indonesia adalah membangun image internasional dengan mempromosikan demokrasi dan perkembangan ekonomi (Bandoro, 2014:146).

Kebijakan luar negeri pada masa pemerintahan Presiden Abdurrhaman Wahid, Megawati Soekarno Putri, dan Susilo Bambang Yudhoyono menunjukkan bahwa Indonesia tidak memiliki fokus pada keamanan maritim. Kebijakan luar negeri yang tidak berfokus pada keamanan maritim ini memengaruhi interaksi yang dilakukan oleh Indonesia dengan negara lain. Pada akhirnya, kebijakan luar negeri pada masa pemerintahan ketiga presiden tersebut memengaruhi Indonesia memutuskan untuk tidak bergabung dengan ReCAAP. Mengingat, pada masa cikal bakal ReCAAP terjadi pada masa pemerintahan Presiden Abdurrahman Wahid dan masa awal pembentukan ReCAAP terjadi pada masa pemerintahan Presiden Susilo Bambang Yudhoyono.

Pada masa pemerintahan Presiden Joko Widodo, Indonesia memiliki fokus terhadap maritim dengan adanya visi Indonesia sebagai Poros Maritim Dunia. Pada 13 November 2015 di East Asia Summit, Presiden Joko Widodo menyampaikan visi Indonesia sebagai Poros Maritim Dunia. Dengan adanya visi Poros Maritim Dunia, Indonesia memiliki rencana untuk mencapai visi tersebut, salah satunya adalah meningkatkan kerjasama maritim dengan negara lain (Presiden RI, 2015). Namun, kerjasama maritim dalam menangani perompakan kurang menjadi prioritas utama bagi Indonesia. Kebijakan maritim Indonesia lebih fokus terhadap penanganan illegal 
fishing pada level nasional. Di bawah Menteri Kelautan dan Perikanan, Susi Pudjiastuti, Indonesia telah menenggelamkan 41 kapal yang melakukan illegal fishing di perairan Indonesia pada 20 Mei 2015 dan 37 kapal pada 18 Agustus 2015 (Febrica, 2017: 68). Hal ini menunjukkan bahwa Indonesia memiliki perhatian khusus terhadap kejahatan illegal fishing.

Meskipun pada masa pemerintahan Presiden Joko Widodo memiliki fokus kebijakan luar negeri pada bidang maritim dengan visi Poros Maritim Dunia, Indonesia tidak lantas memberikan fokus utama terhadap masalah perompakan yang terjadi di Selat Malaka. Hal ini ditunjukkan dengan tidak bergabungnya Indonesia dengan ReCAAP untuk menangani perompakan di wilayah Selat Malaka dan perairan Indonesia. Namun, Indonesia berperan penting dalam kerjasama maritim the Indian Ocean Rim Association (IORA). Indonesia menjadi ketua IORA pada tahun 2015 dan 2016 (IORA, 2016). Hal ini menunjukkan bahwa pada masa kepemimpinan Presiden Joko Widodo, Indonesia memberikan perhatian pada kerjasama maritim, namun kurang memberikan perhatian terhadap penanganan perompakan di Selat Malaka.

Nilai yang dibawa oleh ReCAAP dan IORA kemungkinan memiliki perbedaan yang mendorong Indonesia bergabung dengan IORA dan tidak bergabung dengan ReCAAP. IORA merupakan kerjasama maritim tidak hanya di bidang keamanan maritim, namun juga bidang perdagangan, perikanan, pengetahuan, teknologi, dan pariwisata (IORA, 2017). IORA memiliki 21 negara anggota yang merupakan negara-negara di sekitar wilayah Samudera Hindia, yaitu Australia, Bangladesh, Komoro, India, Indonesia, Iran, Kenya, Madagaskar, Malaysia, Mauritius, Mozambik, Oman, Seychelles, Singapura, Somalia, Afrika Selatan, Sri Lanka, Tanzania, Thailand, Uni Emirat Arab, dan Yaman. Dapat dilihat bahwa IORA tidak beranggotakan negara-negara 'kekuatan ekstra-regional' seperti Amerika Serikat, Jepang, dan China. Ketiga negara ini hanya menjadi dialogue partner. Hal ini menyebabkan nilai yang dibawa oleh IORA berbeda dengan ReCAAP yang dari awal pembentukan sudah terdapat campur tangan 'kekuatan ekstra-regional' yaitu Jepang.

\section{Norma dan Kebijakan Indonesia terhadap ReCAAP}

Perompakan merupakan ancaman bagi setiap negara, namun cara negara memberikan definisi terhadap perompakan dapat memengaruhi penanganan perompakan. Dalam hal ini, negara seperti Jepang melihat perompakan sebagai ancaman bersama yang dibutuhkan kerjasama untuk menanganinya. ReCAAP sebagai kerjasama yang diinisiasi Jepang juga melihat perompakan sebagai ancaman bersama sehingga cara menanganinya adalah dengan melakukan kerjasama.

Berbeda dengan Jepang, Indonesia melihat perompakan yang terjadi di wilayah Asia Tenggara merupakan kejahatan yang terjadi di wilayah 
yurisdiksinya. Indonesia memiliki jumlah perompakan paling tinggi dibandingkan wilayah lain di Asia. Oleh karena itu, Indonesia melihat bahwa cara menangani perompakan ini dengan hukum nasional Indonesia dan tidak dengan melibatkan negara lain.

ReCAAP menggunakan definisi pembajakan laut sesuai dengan United Nations Convention on the Law of the Sea (UNCLOS). Pada UNCLOS menyebutkan bahwa kejahatan perompakan yang terjadi di laut lepas merupakan 'piracy'. UNCLOS menyebutkan bahwa kejahatan pembajakan ini dibutuhkan kerjasama antar negara dalam menanganinya. Secara detail, Pasal 101 dalam UNCLOS (1982) menjelaskan pembajakan adalah sebagai berikut:

a. setiap tindakan ilegal kekerasan atau penahanan, atau tindakan penyusutan, dilakukan untuk tujuan pribadi oleh awak atau penumpang dari kapal swasta dan ditujukan:

i. di laut lepas, terhadap kapal lain, atau terhadap orang atau properti diatas kapal;

ii. terhadap kapal, orang, atau properti di luar wilayah jurisdiksi negara manapun;

b. setiap tindakan sukarela yang mendukung pengoperasian kapal untuk pembajakan;

c. setiap tindakan menghasut atau sengaja memfasilitasi tindakan yang dijelaskan dalam subparagraf (a) atau (b).

Indonesia telah meratifikasi UNCLOS dan memiliki persamaan dalam memandang kejahatan pembajakan. Di samping itu, Indonesia juga merumuskan kejahatan perompakan yang terjadi di wilayah kedaulatan Indonesia. Hal ini berarti Indonesia dapat menindak perompakan yang terjadi di wilayah Indonesia. Pasal 439 KUHP menjelaskan kejahatan pelayaran yan merupakan perompakan yang terjadi di wilayah kedaulatan Indonesia. Kejahatan pelayaran ini terdapat pada pasal 439 KUHP yang berbunyi sebagai berikut:

1) Diancam karena melakukan pembajakan di pantai dengan pidana penjara paling lama 15 (lima belas) tahun, barang siapa dengan memakai kapal melakukan perbuatan kekerasan terhadap kapal lain atau terhadap orang atau barang diatasnya, di dalam wilayah laut Indonesia.

2) Wilayah laut Indonesia yaitu wilayah "territorial zee en maritime kringen Ordonantie" 1939.

Penjelasan di atas menunjukkan bahwa Indonesia memiliki hukum nasional yang mengatur penindakan kejahatan perompakan di wilayah kedaulatan Indonesia. Implikasinya, perompakan yang terjadi di wilayah Indonesia dapat dikenai hukum yang berlaku di Indonesia. Indonesia melihat penanganan perompakanmerupakan kewenanganIndonesiakarena merupakan kejahatan yang terjadi di perairan teritorialnya. Sedangkan, ReCAAP melihat penanganan perompakan dibutuhkan kerjasama seluruh 
anggota sehingga dimungkinkan melakukan penanganan di wilayah yurisdiksi negara lain. Hal ini menunjukkan bahwa terdapat perbedaan pandangan dalam penanganan perompakan. Perbedaan pandangan ini kemudian memengaruhi Indonesia tidak bergabung dengan ReCAAP dalam menangani perompakan di Selat Malaka dan perairan Indonesia.

Jepang dan Indonesia juga memiliki perbedaan dalam melihat ancaman perompakan di Selat Malaka. Jepang melihat perompakan yang terjadi di Selat Malaka tidak hanya ancaman bagi keamanan maritim, melainkan juga merupakan ancaman bagi perdamaian dan stabilitas Jepang (MOFA Japan, 2006). Selain itu, Jepang menganggap ancaman perompakan dapat memberikan dampak pada stabilitas sosial dan kemakmuran ekonomi di seluruh wilayah. Hal ini dikarenakan ancaman perompakan dapat mengganggu distribusi perdagangan internasional (MOFA Japan, 2001).

Sementara itu, Indonesia melihat ancaman perompakan di Selat Malaka merupakan ancaman bagi teritorial wilayah Indonesia. Oleh karena itu, Indonesia membentuk inisiatif nasional untuk menangani perompakan di Selat Malaka, seperti Operasi Gurita, Bakorkamla Routine Patrol, Operasi Sepanjang Tahun, Operasi Kamla, Operasi Trisila, Operasi Satuan Tugas Muara Perairan, dan Air Patrol (Febrica, 2017: 46). Hal ini berbeda dengan inisiatif yang dibuat oleh Jepang yang condong pada kerjasama ekstra regional.

Sesuai asumsi kontruktivis, negara akan melakukan kerjasama dengan negara lain ketika nilai negara-negara ini memiliki persamaan. Sebaliknya, negara dimungkinkan tidak melakukan kerjasama dengan pertimbangan perbedaan nilai yang melekat pada negara tersebut dan negara lain. Perbedaan nilai dalam ReCAAP dan Indonesia ini yang dapat mendorong ketidakikutsertaan Indonesia dalam ReCAAP. Karena Jepang adalah inisiator ReCAAP, nilai yang melekat pada ReCAAP merupakan cerminan nilai pada Jepang. Nilai yang dibawa oleh Jepang ini merupakan pembentukan value-based community, yaitu menciptakan komunitas yang memiliki nilai sama. Jepang menyebarkan suatu regionalisme yang lebih terbuka dengan memelihara hubungan persahabatan dengan negara ekstra regional. Regionalisme lebih terbuka yang dilakukan oleh Jepang ini dapat dilihat dari perkuatan hubungan Jepang dengan negara-negara ASEAN pada tahun 2002. Prinsip yang dibangun Jepang dalam melakukan kerjasama ini adalah keterbukaan (openness), fleksibilitas (flexibility), transparansi (transparency), dan inklusivitas (inclusiveness). Jepang juga menekankan bahwa universal values merupakan hal yang penting pada suatu komunitas (Sohn, 2010).

Jepang memiliki prinsip atau nilai keterbukaan, fleksibilitas, dan transparansi dalam melakukan kerjasama. Hal ini dapat dilihat dari karakteristik ReCAAP yang merupakan inisiasi Jepang. ReCAAP 
mendorong negara-negara penandatangan untuk melakukan implementasi dalam kerjasama ReCAAP, seperti pembentukan ISC dan Focal Point pada masing-masing negara. Dalam kerjasama ReCAAP juga dibutuhkan saling keterbukaan dan transparansi antar negara sehingga dapat terwujud shared value. Dengan adanya prinsip keterbukaan dan transparansi ini dimungkinkanantarnegarapenandatanganReCAAPmelakukan pertukaran informasi terkait tindak kejahatan perompakan yang terjadi di masingmasing negara penandatangan. Selain itu, penanganan kasus perompakan juga dimungkinkan keterlibatan negara-negara penandatangan ReCAAP atas dasar prinsip keterbukaan dan transparansi.

Nilai keterbukaan, fleksibilitas, dan transparansi yang dibawa Jepang melalui ReCAAP ini bertolak belakang dengan prinsip non-intervensi bagi Indonesia. Prinsip non-intervensi ini mencegah campur tangan luar negara dalam menyelesaikan masalah dalam negeri. Selain itu, Indonesia juga memiliki kepentingan nasional memelihara kedaulatan maritim (Yani dan Montratama, 2017: 99). Hal ini menunjukkan Indonesia mencegah adanya peran negara luar yang kemungkinan akan mengganggu kedaulatan Indonesia. Jika Indonesia memutuskan untuk bergabung dengan ReCAAP, maka Indonesia juga harus menyerahkan kedaulatan negara dengan adanya peran negara luar untuk menangani perompakan yang terjadi di perairan Indonesia. Dalam hal ini, Jepang merupakan negara yang kemungkinan akan turun tangan dalam penanganan perompakan di perairan Indonesia. Adanya campur tangan negara lain ini akan mengakibatkan ancaman bagi kedaulatan Indonesia.

Prinsip non-intervensi Indonesia ini kemudian mendorong Indonesia menganut norm subsidiarity. ReCAAP merupakan kerjasama antar negara yang dibentuk oleh Jepang. Dengan adanya Jepang ini maka kerjasama untuk menangani perompakan di wilayah Asia, termasuk Selat Malaka memiliki campur tangan kekuatan ekstra-regional. Jepang yang secara geografis merupakan negara kawasan Asia Timur memiliki peran dalam menangani perompakan di wilayah Asia Tenggara, yaitu Selat Malaka. Peran Jepang ini merupakan kekuatan ekstra regional. Jepang menggunakan nilai-nilai yang melekat pada Jepang, seperti keterbukaan dan transparansi, untuk melakukan kerjasama dalam ReCAAP. Oleh karena itu, Indonesia yang menganut nilai non-intervensi tidak bergabung dengan ReCAAP karena terdapat kekuatan ekstra regional yaitu Jepang.

Indonesia menghindari kerjasama dengan kekuatan ekstra regional. Jepang memiliki potensi untuk dianggap sebagai negara kekuatan ekstraregional dalam kerjasama ReCAAP. Jepang merupakan negara yang menginisiasi pembentukan ReCAAP. Selain itu, Jepang juga berperan aktif melakukan dialog dalam menangani perompakan di wilayah Asia Tenggara dan juga memberikan donor dana dalam penanganan perompakan. Jepang juga membentuk ISC di Singapura. Sehingga, upaya-upaya Jepang 
tersebut dapat dilihat sebagai campur tangan kekuatan ekstra regional di wilayah Selat Malaka. Indonesia yang menganut prinsip non-intervensi menghindari adanya campur tangan kekuatan ekstra regional di wilayah yang bersinggungan dengan teriorialnya.

Indonesia lebih memilih melakukan kerjasama dengan negara-negara tetangga, seperti Singapura dan Malaysia, untuk menangani perompakan di wilayah Selat Malaka. Indonesia melakukan kerjasama dengan negara pantai Selat Malaka, yaitu Malaysia dan Singapura, yang disebut dengan Operasi MALSINDO (Malaysia, Singapura, dan Indonesia). Ketiga negara pantai Selat Malaka ini mulai membentuk Operation MALSINDO pada Juli 2004. Operation MALSINDO merupakan coordinated patrols antara ketiga negara yang bertujuan untuk menangani perompakan di Selat Malaka (Herbert-Burns et.al, 2009: 265). Dengan adanya kerjasama ketiga negara ini dapat menjadi upaya untuk menangani perompakan di Selat Malaka dengan mengurangi peran dari kekuatan ekstra-regional.

Prinsip Indonesia untuk mengurangi peran kekuatan ekstraregional dalam keamanan negara ini sesuai dengan konsep ketahanan nasional. Indonesia yang memiliki prinsip ketahanan nasional ini berarti bahwa Indonesia menekankan konsep inward-looking dalam mengatasi permasalahan keamanan negara. Konsep inward-looking Indonesia ini memiliki artibahwa dalam upaya menegakkan keamanannasional Indonesia tidak dengan aliansi militer maupun di bawah militer negara great power manapun (Acharya, 2001: 72). Hal ini menunjukkan bahwa Indonesia secara mandiri menyelesaikan masalah keamanan yang ada di wilayah Indonesia termasuk perompakan yang terjadi di wilayah kedaulatan Indonesia.

Berbeda dengan Indonesia, Singapura memilih untuk bergabung dengan ReCAAP dan tetap melakukan kerjasama dengan negara tetangga dalam menangani perompakan. Singapura memiliki pandangan outwardlooking dalam mengatasi permasalahan. Sebagai negara kecil, Singapura menjalin hubungan erat dengan negara-negara super power seperti Amerika Serikat dan sekutunya. Singapura memiliki prinsip pro-aktif dalam menangani permasalahan (Leifer, 2000: 7). Lebih lanjut, Singapura juga menyampaikan dukungan adanya kekuatan Barat sebagai unsur penting dalam keamanan nasional dan regional (Acharya, 2001: 68).

Hubungan kerjasama yang dilakukan Singapura dengan negaranegara Barat ini tidak lantas mengurangi keinginan Singapura untuk melakukan kerjasama dengan negara-negara di kawasan. Singapura sebagai negara kecil di kawasan akan menjaga hubungan baik dengan negaranegara di sekitar untuk tetap mempertahankan keamanan negaranya. Oleh karena itu, meskipun Singapura melakukan kerjasama dengan negaranegara Barat, tetapi Singapura tetap menjaga hubungan baik dengan negara-negara di kawasan dengan aktif melakukan kerjasama. Hal ini juga yang mendasari Singapura bergabung dalam ReCAAP, namun tetap 
melakukan kerjasama dengan Malaysia dan Indonesia untuk menangani perompakan di wilayahnya seperti MALSINDO.

Indonesia melakukan kerjasama dengan Malaysia dan Singapura sebagai bentuk perwujudan norm subsidiarity. Dengan adanya kerjasama antara ketiga negara pantai di Selat Malaka ini diharapkan dapat mengurangi dominasi dari kekuatan ekstra regional, seperti kekuatan Jepang melalui ReCAAP. Norm subsidiarity ini juga dipengaruhi oleh nilai yang melekat pada Indonesia, yaitu non-intervensi. Indonesia melakukan kerjasama melalui coordinated patrols dalam Operasi MALSINDO tergolong tidak mengganggu kedulatan Indonesia dibandingkan dengan bergabung di ReCAAP. Jika Indonesia bergabung dengan ReCAAP dapat dimungkinkan akan mengganggu kedaulatan Indonesia karena adanya Jepang yang ikut menangani perompakan di Selat Malaka, bahkan di perairan Indonesia.

Kerjasama Indonesia dalam Operasi MALSINDO ini tergolong working issues jointly dalam zona kerjasama internasional. Berbeda dengan kerjasama dalam ReCAAP yang dapat digolongkan pada extensive collaboration. Zona kerjasama internasional dalam extensive collaboration ini dimungkinkan pembuatan keputusan oleh satu negara dan negara lain akan otomatis mengikuti keputusan tersebut. Hal ini dikarenakan extensive collaboration ini merupakan zona setiap negara memiliki kepercayaan dan adanya shared values. ReCAAP dapat digolongkan pada extensive collaboration ini, karena Jepang sebagai negara pemimpin ReCAAP dapat membuat keputusan yang kemudian diikuti oleh negara-negara penandatangan. Sedangkan, kerjasama Operasi MALSINDO terbatas pada working issues jointly dan masing-masing negara tidak dapat mengganggu kedaulatan negara lain.

Pada akhirnya, perbedaan nilai antara Indonesia dengan ReCAAP mendorong Indonesia lebih memilih kerjasama trilateral dibandingkan kerjasama regional dalam menangani perompakan di Selat Malaka. Adanya kekuatan ekstra regional membuat Indonesia enggan melakukan kerjasama karena prinsip non-intervensi. Nilai yang dimiliki Indonesia ini melekat pada identitas Indonesia sebagai negara berdaulat, sehingga kepentingan Indonesia adalah untuk tetap menjaga kedaulatan Indonesia dari campur tangan kekuatan ekstra regional. Oleh karena itu, Indonesia tidak bergabung dengan ReCAAP karena adanya campur tangan Jepang sebagai kekuatan ekstra regional untuk menangani perompakan di Selat Malaka.

\section{Kesimpulan}

Artikel ini menunjukkan bahwa faktor non-material perlu diperhatikan untuk menganalisis alasan suatu negara melakukan atau tidak melakukan kerjasama. Faktor non-material ini, seperti sejarah, nilai, dan norma, merupakan faktor yang sama pentingnya dengan faktor material. 
Faktor non-material ini dapat membentuk identitas negara yang kemudian memengaruhi kepentingan dan perilaku negara. Seperti halnya Indonesia yang tidak bergabung dengan ReCAAP karena mempertimbangkan faktor non-material yang dimiliki oleh kedua pihak. Indonesia memiliki nilai yang berbeda dengan Jepang sebagai negara penginisiasi ReCAAP. Sehingga, nilai yang berbeda ini memengaruhi cara pandang negara untuk menangani suatu isu dalam kerjasama. Indonesia lebih memilih menangani perompakan dengan melakukan kerjasama dengan negara pantai Selat Malaka, yaitu Malaysia dan Singapura, karena berdasarkan norm subsidiarity.

Indonesia sebagai negara maritim diharapkan dapat berperan dominan dalam kerjasama menangani isu keamanan maritim di kawasan. Adanya kekuatan ekstra-regional menjadi suatu tantangan bagi Indonesia dalam menjalin kerjasama kawasan. Indonesia seharusnya dapat mengambil kesempatan dengan mengambil peran dalam kerjasama yang melibatkan negara-negara ASEAN dengan penguatan kembali nilai-nilai yang dimiliki oleh ASEAN. Indonesia dapat menjadi pelopor suatu kerjasama menangani perompakan di kawasan Asia Tenggara yang didasarkan pada nilai dan norma ASEAN. Indonesia juga perlu memperkuat identitas Indonesia sebagai negara maritim untuk dapat menginisiasi kerjasama maritim di regional Asia Tenggara. Dengan adanya visi Poros Maritim Dunia, Indonesia diharapkan dapat mengambil kesempatan untuk membangun identitas maritim yang kuat.

\section{Daftar Pustaka}

Acharya, A. (2001) Constructing a Security Community in Southeast Asia: ASEAN and the Problem of Regional Order. New York: Routledge.

Bandoro, B. (2014) States' Choice of Strategies. Yogyakarta: Graha Ilmu.

Black, L. (2014) Japan's Maritime Security Strategy: The Japan Coast Guard and Maritime Outlaws. London: Palgrave Macmillan.

Chaikin, G. (2005). Piracy in Asia: International Co-operation and Japan's Role. In Johnson, D. \& Valencia, M. Piracy in Southeast Asia: Status, Issues, and Responses. Singapura: ISEAS.

Connelly, A. L. (2015). Sovereignty and the Sea: President Joko Widodo's Foreign Policy Challenges. Contemporary Southeast Asia 37(1), pp. $1-28$.

Febrica, S. (2015). Why Cooperate? Indonesia and Anti-Maritime Terrorism Cooperation. Asian Politics \& Policy 7(1), pp. 105-130.

Febrica, S. (2017) Maritime Security and Indonesia: Cooperation, Interests and Strategies. New York: Routledge.

Grieco, J. M. (1988). Anarchy and the Limits of Cooperation: A Realist Critique of the newest Liberal Institutionalism. International Organization 42(3), pp. 485-507. 
Herbert-Burns, R. et.al. (2009) Lloyd's MIU Handbook of Maritime Security. London: Routledge.

IORA (2016) Chair, The Indian Ocean Rim Association. Available at: <http:// www.iora.net/chair.aspx> [accessed on 24 October 2017].

IORA (2017) Priority Areas, The Indian Rim Association. Available at: $<$ http://www.iora.net/about-us/priority-areas.aspx> [accessed on 24 October 2017].

Keohane, R. O. \& Martin, L. L. (1995). The Promise of Institutionalist Theory. International Security 20(1), pp. 39-51.

Keohane, R. O. \& Nye, J. S. eds. (2012) Power and Interdependence. New York: Pearson.

Khalid, N. (2009). With a Little Help from My Friends: Maritime Capacitybuilding Measures in the Straits of Malacca. Contemporary Southeast Asia 31(3), pp. 424-446.

KUHP, Kitab Undang-Undang Hukum Pidana (2007).

Lee, T. \& McGahan, K. (2015). Norm Subsidiarity and Institutional Cooperation: Explaining the Straits of Malacca Anti-Piracy Regime. The Pacific Review 28(4), pp. 529-552.

Leifer, M. (2000) Singapore's Foreign Policy Coping with Vulnerability. New York: Routledge.

Liss, C. (2013). New Actors and the State: Addressing Maritime Security Threats in Southeast Asia. Contemporary Southeast Asia 35(2), pp. 141-162.

Mearsheimer, J. J. (1995). The False Promise of International Institutions. International Security 19(3), pp. 5-49.

MOFA Japan (2001) Present State of the Piracy Problem and Japan's Effort (online). Available at: <http://www.mofa.go.jp/policy/piracy/ problem0112.html $>$ [accessed on 21 October 2017].

MOFA Japan (2006) Regional Cooperation Agreement on Combating Piracy and Armed Robbery against Ships in Asia (ReCAAP): Mr. Yoshiaki Ito to Take Office as Executive Director of Information Sharing Center (ISC) (online). Available at: <http://www.mofa.go.jp/ announce/announce/2006/11/1128-3.html> [accessed on 21 October 2017].

Pattiradjawane, R. L. (2016). The Indonesia Perspective toward Rising China: Balancing the National Interest. Asian Journal of Comparative Politics 1(3), pp. 260-282.

Pattiradjawane, R. L. \& Soebagjo, N. (2015). Global Maritime Axis: Indonesia, China, and a New Approach to Southeast Asian Regional Resilience. International Journal of China Studies 6(2), pp. 175-185.

Presiden RI (2015) Indonesia sebagai Poros Maritim Dunia (online). Available at: <http://www.presidenri.go.id/berita-aktual/indonesiasebagai-poros-maritim-dunia.html $>$ [accessed on 23 October 2017]. 
Quirk, S. \& Bradford, J. (2015). Maritime Fulcrum: A New US Opportunity to Engage Indonesia. Pacific Forum CSIS 15(9), pp. 1-11.

ReCAAP (2007) ReCAAP ISC Annual Research Report 2007 (online). Available at: <http://www.recaap.org/DesktopModules/ Bring $2 \mathrm{mind} / \mathrm{DMX} / \mathrm{D}$ ownload . as px? Com mand=Core Download\&EntryId=51\&PortalId $=0 \& T a b I d=78>$ [accessed on 3 October 2017].

ReCAAP(2016)CommemoratingaDecadeofRegionalCooperation2006-2016 (online). Available at: <http://www.recaap.org/DesktopModules/ Bring $2 \mathrm{mind} / \mathrm{DMX} / \mathrm{D}$ ownload.as px? Com mand =Core Download\&EntryId $=432 \&$ Portalld $=0 \&$ TabId $=78>$ [accessed on 23 October 2017].

ReCAAP (2017) About the ReCAAP and the ReCAAP Information Sharing Centre (online). Available at: < http://www.recaap.org/ AboutReCAAPISC.aspx> [accessed on 2 October 2017].

Reus-Smit, C. (2005). Constructivism. In: Burchill, S. \& Linklater, A. Theories of International Relations. New York: Palgrave Macmillan.

Rosyidin, M. (2017). Foreign Policy in Changing Global Politics: Indonesia's Foreign Policy and the Quest for Major Power Status in the Asian Century. Southeast Asia Research 17(1), pp. 1-17.

Sohn, Y. (2010). Japan's New Regionalism: China Shock, Values, and the East Asian Community. Asian Survey 50(3), pp. 497-519.

UNCLOS (1982) United Nations Convention on the Law of the Sea (online). Available at: <http://www.un.org/Depts/los/convention_ agreements/texts/unclos/unclos_e.pdf $>$ [accessed on 21 October 2017].

Viotti, P. R. \& Kauppi, M. V. eds. (2009). International Relations and World Politics: Security, Economy, Identity. New Jersey: Pearson.

Wendt, A. (1992). Anarchy is What States Make of it: The Social Construction of Power Politics. International Organization 46(2), pp. 391-425.

Yani, Y. M. \& Montratama, I. (2017). Quo Vadis Politik Luar Negeri Indonesia. Jakarta: Kompas Gramedia. 